BRAVZULIAN JOURNAL

OF MEDICAL AND BIOLOGICAL RESH.ARCH

www.bjournal.com.br
ISSN 0100-879X

Volume 44 (7) 606-728 July 2011

BIOMEDICAL SCIENCES

AND

CLINICAL INVESTIGATION

Braz J Med Biol Res, July 2011, Volume 44(7) 666-670

doi: 10.1590/S0100-879X2011007500062

\title{
Dynamics of immunosuppression in hamsters with experimental visceral leishmaniasis
}

C. Fazzani, P.A. Guedes, A. Sena, E.B. Souza, H. Goto and J.A.L. Lindoso

The Brazilian Journal of Medical and Biological Research is partially financed by

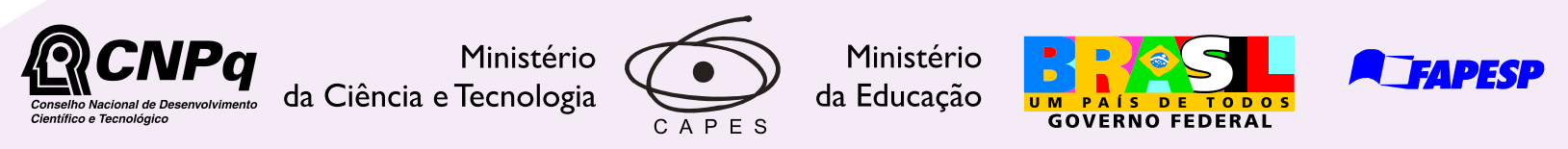

Institutional Sponsors
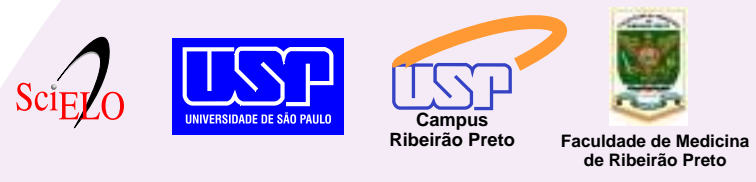
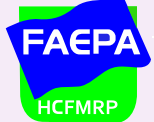

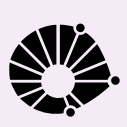

Ф SHIMADZU

GE Healthcare
Hotsite of proteomics metabolomics developped by:

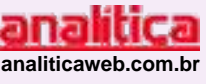

Thermo SCIENTIFIC 


\title{
Dynamics of immunosuppression in hamsters with experimental visceral leishmaniasis
}

\author{
C. Fazzani ${ }^{1,2}$, P.A. Guedes ${ }^{1}$, A. Sena ${ }^{1}$, E.B. Souza ${ }^{1}$, H. Goto ${ }^{1,3}$ and J.A.L. Lindoso ${ }^{1,4}$ \\ ${ }^{1}$ Laboratório de Soroepidemiologia e Imunobiologia (LIM-38), Instituto de Medicina Tropical de São Paulo, \\ 2Departamento de Fisiopatologia Experimental, ${ }^{3}$ Departamento de Medicina Preventiva, Faculdade de Medicina, \\ Universidade de São Paulo, São Paulo, SP, Brasil \\ ${ }^{4}$ Instituto de Infectologia Emilio Ribas, Secretaria Estadual da Saúde, São Paulo, SP, Brasil
}

\begin{abstract}
Immunosuppression has been reported to occur during active visceral leishmaniasis and some factors such as the cytokine profile may be involved in this process. In the mouse model of cutaneous leishmaniasis using Leishmania (Leishmania) major, the Th1 response is related to protection while the Th2 response is related to disease progression. However, in hamsters, which are considered to be an excellent model for the study of visceral leishmaniasis, this dichotomy is not observed. Using outbred 45 - to 60 -day-old (140 to $150 \mathrm{~g}$ ) male hamsters infected intraperitoneally with $2 \times 10^{7} \mathrm{~L}$. (L.) chagasi amastigotes, we evaluated the immune response of spleen cells and the production of cytokines. We used 3 to 7 hamsters per group evaluated. We detected a preserved response to concanavalin A measured by index of proliferation during all periods of infection studied, while a proliferative response to Leishmania antigen was detected only at 48 and $72 \mathrm{~h}$ post-infection. Messenger RNA from cytokines type 1 (IL-2, TNF- $\alpha$, IFN- $\gamma$ ) and type 2 (IL-4, IL-10 and TGF- $\beta$ ) detected by reverse transcriptase polymerase chain reaction and produced by spleen cells showed no qualitative difference between control non-infected hamsters and infected hamsters during any period of infection evaluated. Cytokines were measured by the DNA band intensity on agarose gel using the Image Lab 1D L340 software with no differences observed. In conclusion, the present results showed an antigen-dependent immunosuppression in hamsters with active visceral leishmaniasis that was not related to the cytokine profile.
\end{abstract}

Key words: Immunosuppression; Leishmania (Leishmania) chagasi; Hamster; Cytokine; T-cell proliferation

\section{Introduction}

Active visceral leishmaniasis $(\mathrm{VL})$ is accompanied by impairment of the T-cell response and can be fatal if not treated. During VL the suppression of Leishmania antigen- or mitogeninduced $T$ cell-mediated immune responses is observed both in humans and in experimental animals (1-3). Leishmania-infected hamsters are considered to be an excellent experimental model for the evaluation of immunosuppression during VL since their disease is similar to the human disease with weight loss, hepatosplenomegaly and hypergammaglobulinemia (3-5). In this experimental model, immunosuppression is observed during active disease and a progressive impairment of Leishmania antigen-and concanavalin $\mathrm{A}(\mathrm{Con} \mathrm{A})$-induced lymphoproliferative response has been demonstrated. Some host-related factors may be involved in the development of immunosuppression, which is partially attributed to Leishmania antigen-specific suppression, participation of non-adherent cells, possibly $\mathrm{T}$ lymphocytes (4), and reduced nitric oxide production by adherent cells from Leishmania-infected hamsters $(5,6)$. Furthermore, an increased production of transforming growth factor- $\beta$ (TGF- $\beta$ ) by the spleen or peripheral blood mononuclear cells of Leishmania-infected hamsters or Leishmania-infected mouse $T$ cells has been related to immunosuppression (7-9) and to the impairment of protein kinase $\mathrm{C}$ activity or expansion of $\mathrm{CD} 4^{+} \mathrm{CD} 25^{+}$cells $(8,9)$. However, using reverse transcriptase (RT)-PCR, dichotomy between the Th1 and Th2 cytokine profiles has not been observed during active VL in Leishmania donovani-infected hamsters (10). These results have been obtained during the late and intermediate phases of infection, but suppression is likely to occur during the initial phase of infection. Thus, in the present study, we evaluated the immune response and cytokine profile of hamsters infected with $L$. (L.) chagasi during the initial, intermediate and late phases of infection.

\section{Material and Methods}

\author{
Animals \\ Outbred 45- to 60-day-old male hamsters (Mesocricetus
}

Correspondence: J.A.L. Lindoso, Laboratório de Soroepidemiologia e Imunobiologia, IMT, USP, Av. Dr. Eneas C. Aguiar, 500, 05403-000 São Paulo, SP, Brasil. Fax: +55-11-3061-7023. E-mail: jlindoso@usp.br

Received October 25, 2010. Accepted April 29, 2011. Available online May 13, 2011. Published July 25, 2011. 
auratus) from the animal breeding facility of Faculdade de Medicina, Universidade de São Paulo, were maintained at the animal facility of Instituto de Medicina Tropical de São Paulo, Universidade de São Paulo, with free access to water and food throughout experiment.

\section{Parasite}

Leishmania (L.) chagasi (MHOM/BR/72/strain 46) were maintained in hamsters by successive inoculations with an infected spleen homogenate every 3 months. For the experiments, hamsters with VL after 2-3 months of infection were sacrificed under anesthesia $(20 \mathrm{mg} / \mathrm{kg}$ ketamine and $5 \mathrm{mg} /$ $\mathrm{kg}$ xylazine), the spleen was removed aseptically and the amastigotes were purified by the method of Dwyer (11).

\section{Experimental protocol}

Three to 7 hamsters per experimental group were inoculated intraperitoneally with $2 \times 10^{7}$ purified amastigotes in $1.0 \mathrm{~mL} 199$ medium (Cultilab, Brazil). Four control animals were injected with $1.0 \mathrm{~mL} 199$ medium. The animals were sacrificed and the spleens were weighed for analysis of parasite load on spleen imprints. In addition, ex vivo spleen cells were used to measure the proliferative response and to analyze the qualitative and semi-quantitative cytokine profile by RT-PCR.

\section{In vitro spleen cell culture}

Erythrocytes from the spleen homogenate were lysed with $2 \%$ ammonium chloride in distilled water for $2 \mathrm{~min}$, the osmolarity was immediately adjusted with $10 \mathrm{X}$ phosphatebuffered saline and the preparation was washed twice in RPMI 1640 medium. The cell concentration was adjusted to $2 \times 10^{7}$ cells/mL in RPMI 1640 medium supplemented with $10 \mathrm{mM}$ HEPES, $100 \mathrm{IU} / \mathrm{mL}$ penicillin, $10 \mu \mathrm{g} / \mathrm{mL}$ gentamicin, $2 \mu \mathrm{M}$ L-glutamine, $10 \mu \mathrm{M}$ 2-mercaptoethanol (Sigma, USA) and $1 \%$ heat-inactivated control hamster serum. The cell suspension obtained from hamsters was used to evaluate the proliferation and detection of mRNA from cytokines.

\section{Cell-proliferation}

Spleen cells $\left(2 \times 10^{7}\right)$ under culture in 96-well plates were stimulated with $0.5 \mu \mathrm{g}$ Con A (Amersham Pharmacia, Sweden) or $5 \times 10^{7}$ Leishmania antigen for $72 \mathrm{~h}$. Six hours before the end of the culture, cells were pulsed with $1 \mu \mathrm{Ci} /$ well ${ }^{3} \mathrm{H}$-thymidine (specific activity $=5 \mathrm{Ci} / \mathrm{mmol}$; Amersham Life Science, England). They were then harvested with glass fiber filters (Millipore, USA) and counted with a $\beta$ counter (Packard, USA). Data are reported as proliferation index as count per minute $(\mathrm{cpm})$ in triplicate preparations.

The cells cultured in 24-well plates were processed for the detection of the qualitative and quantitative cytokine profile by RT-PCR.

\section{Qualitative and quantitative cytokine profile}

Extraction of total RNA. Spleen cells ex vivo and in culture upon receiving the stimuli were suspended in 500 $\mu \mathrm{L}$ Trizol reagent (Invitrogen, USA) and incubated at room temperature for $10 \mathrm{~min}$. Chloroform $(200 \mu \mathrm{L})$ was added, and the cultures were homogenized vigorously and then centrifuged at $12,000 \mathrm{~g}$ at $4^{\circ} \mathrm{C}$ for $15 \mathrm{~min}$. Aqueous phase $(500 \mu \mathrm{L})$ was separated, incubated with the same volume of isopropanol for $30 \mathrm{~min}$ at room temperature and then centrifuged. Absolute ethanol $(500 \mu \mathrm{L})$ was added to the pellet, which was centrifuged again at $12,000 \mathrm{~g}$ for $15 \mathrm{~min}$ at $4^{\circ} \mathrm{C}$. Ethanol was discarded and the pellet was dried for $10 \mathrm{~min}$ and suspended in $50 \mu \mathrm{L}$ RNAse-free distilled water. RNA concentration and quality was determined with a NanoDrop-1000 spectrophotometer (NanoDrop Technologies, USA) and by $0.8 \%$ agarose gel electrophoresis and visualized with ethidium bromide.

cDNA preparation. Fifteen microliters of extracted RNA with $0.5 \mu \mathrm{g} / \mu \mathrm{L}$ of the oligo(dT) $12-18$ primer (Invitrogen) and $3 \mu \mathrm{g} / \mu \mathrm{L}$ of a random primer (Invitrogen) were amplified in a thermocycler (Mastercycler Gradient, Eppendorf, Germany) for $5 \mathrm{~min}$ at $75^{\circ} \mathrm{C}$ and for $5 \mathrm{~min}$ at $25^{\circ} \mathrm{C}$. Buffer (5X, Invitrogen), $10 \mathrm{mM}$ dNTPs (Invitrogen), $40 \mathrm{U} / \mu \mathrm{L}$ RNAse (Fermentas, UK), $1000 \mathrm{U}$ reverse transcriptase (Fermentas) and autoclaved ultrapure water were added and submitted to an amplification cycle in a thermocycler for $50 \mathrm{~min}$ at $37^{\circ} \mathrm{C}, 15 \mathrm{~min}$ at $70^{\circ} \mathrm{C}$ and $10 \mathrm{~min}$ at $4^{\circ} \mathrm{C}$. The cDNA concentration and quality were analyzed with a NanoDrop-1000 spectrophotometer (NanoDrop Technologies).

\section{Polymerase chain reaction}

Cytokine initiator oligonucleotides and hamster HPRT were designed by using the respective gene sequences obtained from Gene Bank and synthesized by Gibco BRLLife Technologies (Brazil). HPRT: forward, CCACGCC TACTATAGAGTTTG; reverse, CTTGCGATGTCATGG TAGAG; tumor necrosis factor- $\alpha$ (TNF- $\alpha$ ): forward, CAC AATCCTCTTCTGCCTGC; reverse, TGTCTTTGAGAG ACATCCCG; TGF- $\beta$ : forward, GAGAAGAACTGCTGTG TGCG; reverse, ACCCACGTAGTACACGATGG; interleukin-2 (IL-2): forward, AACCCAGCAGCACCTCGAGC; reverse, CAGTTACTGTCTCATCATCG; interferon- $\gamma$ (IFN-y): forward, TCATTGAGAGCCAGATCGTC; reverse, GGCTAAGTTTTCGTGACAGG; IL-10: forward, GGACAAC ATACTACTCACTG; reverse, ACAGGGGAGAAATCG ATGAC; IL-4: forward, TCCTATCACTGACGGTAGAG; reverse, TGCAAATGAGGTCTTTCTCC. One microliter cDNA was mixed with 10X PCR buffer (Invitrogen), 10 mM dNTP (Invitrogen), $10 \mu \mathrm{M}$ specific forward and reverse primers, $0.65 \mathrm{mM}$ magnesium (Fermentas), $0.75 \mathrm{U} / \mu \mathrm{L}$ Taq DNA polymerase (Fermentas), and autoclaved ultrapure water. Samples were submitted to amplification cycles in a thermocycler (Mastercycler Gradient) for $5 \mathrm{~min}$ at $95^{\circ} \mathrm{C}, 2$ $\min$ at $50^{\circ} \mathrm{C}$ and $2 \mathrm{~min}$ at $70^{\circ} \mathrm{C}$, and to 35 cycles for $1 \mathrm{~min}$ at $95^{\circ} \mathrm{C}, 2 \mathrm{~min}$ at $50^{\circ} \mathrm{C}$ and $2 \mathrm{~min}$ at $70^{\circ} \mathrm{C}$. The amplified product was analyzed on $2.0 \%$ agarose gel and visualized with ethidium bromide. Cytokine mRNA was quantified 
using the Image Lab 1D L340 software that measures the DNA band intensity on agarose gel.

\section{Statistical analysis}

All experiments were carried out in triplicate and a

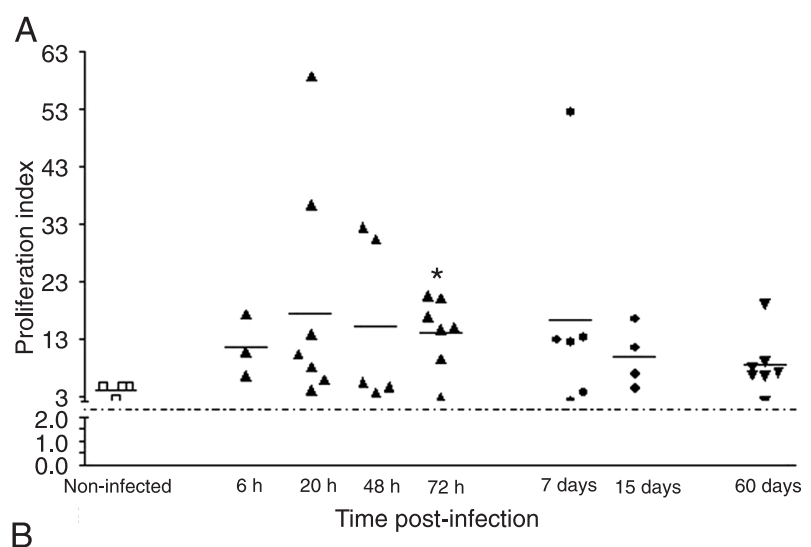

B

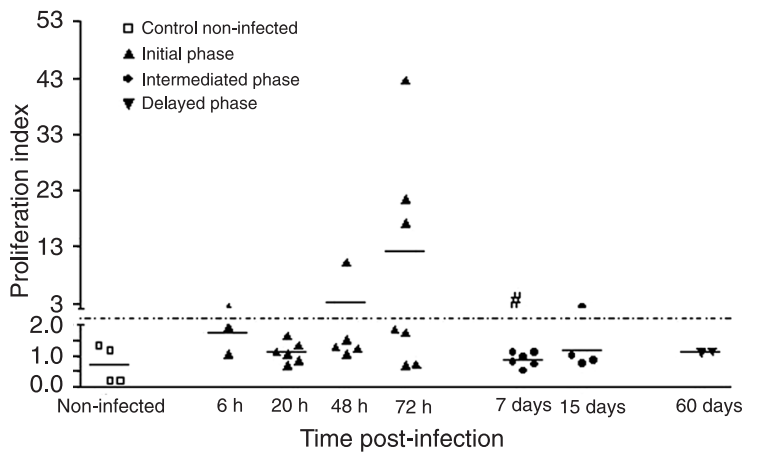

Figure 1. Proliferation of spleen cells of hamsters infected by Leishmania (Leishmania) chagasi. Spleen cells $\left(2 \times 10^{7}\right.$ cells $\left./ \mathrm{mL}\right)$ at initial $(6,20,48$, and $72 \mathrm{~h})$, intermediate ( 7 and 15 days) and late (60 days) time of infection were stimulated with concanavalin A $(0.5 \mu \mathrm{g} / \mathrm{mL})(A)$ or total antigen of LLC $\left(5 \times 10^{7}\right.$ parasites $\left./ \mathrm{mL}\right)$ (B). The results are reported as proliferation index (count per min of stimulated cells/count per min of non-stimulated cells) with a cut-off (dashed line) of 2.0. ${ }^{*} \mathrm{P}<0.05$ vs non-infected; ${ }^{\#} \mathrm{P}<0.05$ vs $48 \mathrm{~h}$ (Kruskal-Wallis test) minimum of four hamsters were used per group according to their infected times or not. Data are reported as means \pm SD and were analyzed by ANOVA. Nonparametric data were analyzed by the Kruskal-Wallis test. The level of significance was set at $P<0.05$ in all analyses.

This study was approved by the Ethics Committee of Instituto de Medicina Tropical, Universidade de São Paulo.

\section{Results}

Initially, we observed a progressive increase of parasite load in the spleen of hamsters infected with L. (L.) chagasi (data not shown). To better understand the increase of parasite burden and progression of the disease in this model, we investigated the proliferative response of spleen cells to a mitogen and a Leishmania antigen. When the spleen cells in culture were stimulated with Con $\mathrm{A}$, the response was preserved during all periods of infection (Figure 1A), but a specific response to Leishmania antigen was only detected at 48 and $72 \mathrm{~h}$ post-infection (pi) (Figure 1B). No proliferation in response to the Leishmania antigen was observed from 7 to 60 days pi. When spleen cells from hamsters immunized with total L. (L.) chagasi antigen were stimulated with Leishmania antigen and presented a proliferative response, they were used as a positive control for antigen proliferation. Using RT-PCR to detect cytokine mRNA in spleen cells from infected hamsters, we observed the presence of mRNA of all cytokines evaluated, i.e., TNF- $\alpha$, TGF- $\beta$, IL-2, IL-4, IL-10, and IFN-y during all periods of infection evaluated (Figure 2), as well as in non-infected cells. As a control of RT-PCR, we detected hamster HPRT. No qualitative and quantitative differences in cytokine mRNA produced by spleen cells were observed between infected and noninfected hamsters (Table 1).

\section{Discussion}

Hamsters infected with Leishmania develop a progressive and severe disease, as is also observed in humans

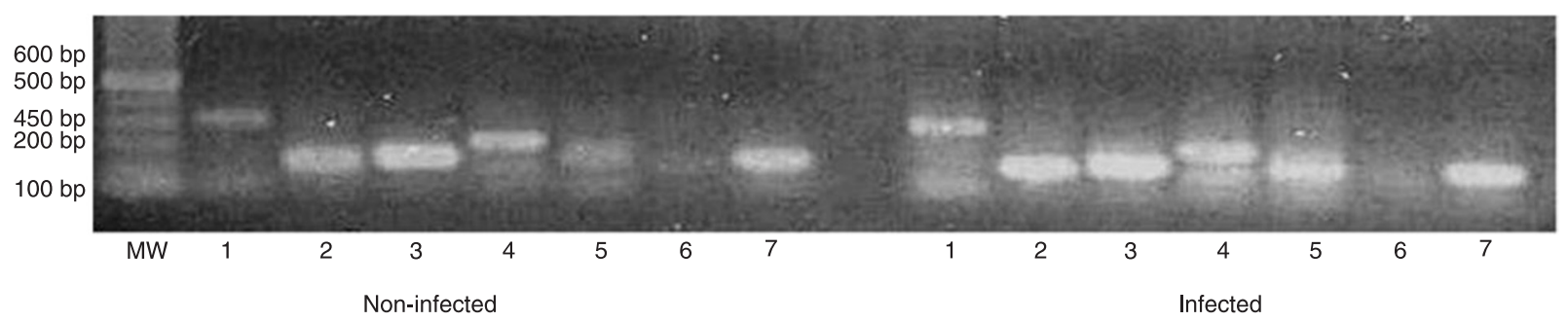

Figure 2. Detection of hamster cytokine mRNA. The mRNA of spleen cells $\left(2 \times 10^{7} \mathrm{cells} / \mathrm{mL}\right)$ was analyzed by reverse transcriptase polymerase chain reaction (RT-PCR) for lane 1 = HPRT (420 bp), lane $2=$ TNF- $\alpha$ (260 bp), lane $3=$ TGF- $\beta$ (270 bp), lane $4=$ IL-2 (400 $\mathrm{bp})$, lane $5=\mathrm{IL}-4(290 \mathrm{bp})$, lane $6=\mathrm{IL}-10(280 \mathrm{bp})$, and lane $7=\mathrm{IFN}-\mathrm{\gamma}(320 \mathrm{bp})$ expression both in non-infected and infected-hamsters (15 days post-infection). MW = molecular weight marker 
with active $\mathrm{VL}$ (12-15). In the present study, we observed a progressive time-dependent increase of parasite burden in the spleen of hamsters, thus confirming that these animals are good models for the development of active VL and for the study of immunosuppression. For a better understanding of VL progression in hamsters, we first evaluated the proliferative response of $T$ cells to a mitogen and to $a$ Leishmania antigen. We observed specific immunosuppression in response to Leishmania antigen, which, however, was limited to the initial phase of infection (48 and $72 \mathrm{~h}$ pi). We have observed a Con A-induced lymphoproliferative response during all experimental periods but a total absence of a Leishmania antigen-induced response in the late phase (3). According to the literature, the Leishmania antigen-induced response was suppressed (13), but there is a disagreement about the Con A-induced response. Some studies showed a response preserved throughout the experiment (13) while others did not observe it after 42 days of infection (14). Some factors, such as route of inoculation, may affect these results. Intracardiac inoculation produces an important impairment of the T-cell proliferative response to both a mitogen and a Leishmania antigen (13), while subcutaneous inoculation induces an immune response to both mitogen and Leishmania antigen $(15,16)$. In the present study, we used the intraperitoneal route of inoculation, which promotes progressive infection and development of disease, indicating the occurrence of progressive immunosuppression during active VL similar to that observed in natural infection. Although hamsters are considered to provide a good model of visceral leishmaniasis, the almost complete absence of markers for T cells, macrophages and cytokines impairs a better understanding of the occurrence of the immune response in this model. However, after cytokine cloning from hamsters (6) there was an improvement in the understanding of the immune response in this experimental model. The profile of Th2 cytokines is directly responsible for suppression, but other factors such as adherent cells (17) and macrophage-mediated suppression have been reported to lead to increasing parasite growth and also to be linked to defective antigen presentation (18). The Th1 cytokine IFN-y plays a key role in the control of infection with many intracellular pathogens, including Leishmania spp, and is the cytokine primarily responsible for macrophage activation and killing of intracellular parasites $(19,20)$. In hamsters infected with $L$. $(L$.) donovani, adherent spleen cells have been shown to be important lymphoproliferative suppressors and to play a role in defective antigen presentation (13). Furthermore, TGF- $\beta$ produced by adherent antigen-presenting cells from infected hamsters has been implicated in immunosuppression since a high level of TGF- $\beta$ was observed in the cell culture supernatant when the Leishmania antigen-induced lymphoproliferative response was inhibited $(7,8)$. In the present study, we investigated the cytokine profile produced during the course of VL by spleen cells in culture upon stimulation with Con $A$ and
Table 1. Quantitation of cytokine mRNA in infected and non-infected control hamsters.

\begin{tabular}{lrrc}
\hline Cytokines & Control & Infected & $\begin{array}{c}\text { Relationship between infected } \\
\text { and non-infected animals }\end{array}$ \\
\hline HPRT & 63.708 & 93.377 & 1.47 \\
TNF- $\alpha$ & 110.038 & 141.333 & 1.28 \\
TGF- $\beta$ & 148.550 & 160.010 & 1.08 \\
IL-2 & 90.505 & 103.582 & 1.14 \\
IL-4 & 86.538 & 124.538 & 1.44 \\
IL-10 & 44.007 & 83.234 & 1.89 \\
IFN-Y & 121.803 & 105.299 & 0.89 \\
\hline
\end{tabular}

Cytokine mRNA was measured using the Image Lab 1D L340 software. Data are reported as DNA band intensity and are representative of only 1 animal from each group. The relationship between infected and non-infected animals was measured by the infected band intensity/non-infected band intensity ratio. TNF- $\alpha=$ tumor necrosis factor- $\alpha$; TGF- $\beta=$ transforming growth factor- $\beta$; IL $=$ interleukin; IFN- $\gamma=$ interferon- $\gamma$.

Leishmania antigen using RT-PCR and we did not observe a qualitative or quantitative change in cytokine expression by non-infected and infected hamsters during any period of infection studied, in agreement with results obtained by Melby et al. (6). These results are similar to those observed in human VL but contrast with the dominant Th2 responses observed in progressive L. major infection in BALB/c mice. The immunosuppression mechanism is not related to the cytokine profile, although the change of a nucleotide in the final portion of sequence of mRNA from IFN- $\gamma$ has been observed in hamsters (6), possibly contributing to a reduction of the biological effect of this cytokine and indicating the absence of power to control the progression of infection. Interestingly, we observed a strong TGF- $\beta$ band during all periods of infection evaluated. We emphasize the importance of TGF- $\beta$ in susceptibility and immunosuppression, a fact that has been demonstrated by the restoration of the proliferative response of non-adherent cells from infected hamsters treated with anti-TGF- $\beta$ (8). It is attractive to speculate about the possible participation of $\mathrm{CD} 4^{+} \mathrm{CD} 25^{+}$regulatory cells in immunosuppression during active $\mathrm{VL}$ in hamsters (9). According to our data, the immunosuppression observed in hamsters during active visceral leishmaniasis is an antigen-specific response since the initial phase of infection (after $72 \mathrm{~h}$ of infection), as determined by the absence of a lymphoproliferative response to Leishmania antigen and a preserved response to Con A. Interestingly, based on our results, the production of cytokines does not contribute to the development of immunosuppression in this experimental model.

\section{Acknowledgments}

Research supported by CAPES, FAPESP, and CNPq. 
C. Fazzani was the recipient of CAPES and FAPESP fellowships. P.A. Guedes and A. Senna were recipients of

\section{References}

1. Carvalho EM, Teixeira RS, Johnson WD Jr. Cell-mediated immunity in American visceral leishmaniasis: reversible immunosuppression during acute infection. Infect Immun 1981; 33: 498-500.

2. Nickol AD, Bonventre PF. Immunosuppression associated with visceral leishmaniasis of hamsters. Parasite Immunol 1985; 7: 439-449.

3. Goto $\mathrm{H}$, Lindoso JA. Immunity and immunosuppression in experimental visceral leishmaniasis. Braz J Med Biol Res 2004; 37: 615-623.

4. Bunn-Moreno MM, Madeira ED, Miller K, Menezes JA, Campos-Neto A. Hypergammaglobulinaemia in Leishmania donovani-infected hamsters: possible association with a polyclonal activator of $B$ cells and with suppression of $T$ cell function. Clin Exp Immunol 1985; 59: 427-434.

5. Dasgupta S, Mookerjee A, Chowdhury SK, Ghose AC. Immunosuppression in hamsters with progressive visceral leishmaniasis: an evaluation of the role of nitric oxide toward impairment of the lymphoproliferative response. Parasitol Res 1999; 85: 594-596.

6. Melby PC, Chandrasekar B, Zhao W, Coe JE. The hamster as a model of human visceral leishmaniasis: progressive disease and impaired generation of nitric oxide in the face of a prominent Th1-like cytokine response. J Immunol 2001; 166: 1912-1920.

7. Rodrigues V Jr, Santana da Silva J, Campos-Neto A. Transforming growth factor beta and immunosuppression in experimental visceral leishmaniasis. Infect Immun 1998; 66: 1233-1236.

8. Mookerjee A, Sen PC, Ghose AC. Immunosuppression in hamsters with progressive visceral leishmaniasis is associated with an impairment of protein kinase $\mathrm{C}$ activity in their lymphocytes that can be partially reversed by okadaic acid or anti-transforming growth factor beta antibody. Infect Immun 2003; 71: 2439-2446.

9. Rodrigues OR, Marques C, Soares-Clemente M, Ferronha $\mathrm{MH}$, Santos-Gomes GM. Identification of regulatory T cells during experimental Leishmania infantum infection. Immunobiology 2009; 214: 101-111.

10. Melby PC, Tryon VV, Chandrasekar B, Freeman GL. Cloning of Syrian hamster (Mesocricetus auratus) cytokine cDNAs and analysis of cytokine mRNA expression in experimental visceral leishmaniasis. Infect Immun 1998; 66: 2135-2142.

11. Dwyer DM. Antibody-induced modulation of Leishmania
FAPESP fellowships. H. Goto was the recipient of a CNPq fellowship. donovani surface membrane antigens. J Immunol 1976; 117: 2081-2091.

12. Barbosa Junior AA, Andrade ZA, Reed SG. The pathology of experimental visceral leishmaniasis in resistant and susceptible lines of inbred mice. Braz J Med Biol Res 1987; 20: 63-72.

13. Rodrigues Junior V, Da Silva JS, Campos-Neto A. Selective inability of spleen antigen presenting cells from Leishmania donovani infected hamsters to mediate specific T cell proliferation to parasite antigens. Parasite Immunol 1992; 14: 49-58.

14. Vasconcellos RC, Urago KP, Bunn-Moreno MM, Madeira ED. Suppressor activity in Leishmania donovani-infected hamster serum: reversion by delipidated bovine serum albumin and role in cell cycle events. Braz J Med Biol Res 1996; 29: 615-622.

15. Gifawesen C, Farrell JP. Comparison of T-cell responses in self-limiting versus progressive visceral Leishmania donovani infections in golden hamsters. Infect Immun 1989; 57 : 3091-3096.

16. Streit JA, Recker TJ, Filho FG, Beverley SM, Wilson ME. Protective immunity against the protozoan Leishmania chagasi is induced by subclinical cutaneous infection with virulent but not avirulent organisms. J Immunol 2001; 166: 1921-1929.

17. Basak SK, Saha B, Bhattacharya A, Roy S. Immunobiological studies on experimental visceral leishmaniasis. II. Adherent cell-mediated down-regulation of delayed-type hypersensitivity response and up-regulation of B cell activation. Eur J Immunol 1992; 22: 2041-2045.

18. Reiner NE, Ng W, McMaster WR. Parasite-accessory cell interactions in murine leishmaniasis. II. Leishmania donovani suppresses macrophage expression of class I and class II major histocompatibility complex gene products. J Immunol 1987; 138: 1926-1932.

19. Heinzel FP, Sadick MD, Holaday BJ, Coffman RL, Locksley RM. Reciprocal expression of interferon gamma or interleukin 4 during the resolution or progression of murine leishmaniasis. Evidence for expansion of distinct helper $\mathrm{T}$ cell subsets. J Exp Med 1989; 169: 59-72.

20. Squires KE, Schreiber RD, McElrath MJ, Rubin BY, Anderson SL, Murray HW. Experimental visceral leishmaniasis: role of endogenous IFN-gamma in host defense and tissue granulomatous response. J Immunol 1989; 143: 4244-4249. 